\title{
HLA-DRB5 wt Allele
}

National Cancer Institute

\section{Source}

National Cancer Institute. HLA-DRB5 wt Allele. NCI Thesaurus. Code C71264.

Human HLA-DRB5 wild-type allele is located in the vicinity of 6p21.3 and is approximately $13 \mathrm{~kb}$ in length. This allele, which encodes HLA class II histocompatibility antigen, DRB5 beta chain protein, is involved in the modulation both of antigen presentation and the immune response. The gene is polymorphic and typing is often performed to determine histocompatibility for hematopoietic stem cell transplantation. 